\title{
PÉNZÜGYEKRŐL MÁSKÉPPEN:
}

\section{FENNTARTHATósÁg ÉS KözösSÉGI PÉNZÜGYEK ${ }^{1}$}

[Pénzügyekröl másképpen: Fenntarthatóság és közösségi

pénzügyek. Szerkesztő: Kerekes Sándor. Budapest:

CompLex Wolters Kluwer, 2016. ISBN 978-963-295-585-8]

Kerekes Sándor neve a legjelentösebb név, ha a fenntarthatóságról szóló mai magyar tudományos eredményeket tekintjük át és keressük a terület legszakavatottabb ismerőjét. A fenntarthatóság értelmezése ma kettős, szükebb értelemben a környezeti-ökológiai, tágabb értelemben mindazokat a társadalmi és gazdasági folyamatokat értjük alatta, amelyek a jövő generáció számára élhetö környezetet biztosítanak. Kerekes Sándor e könyvvel - melynek részben szerkesztöi feladatait is vállalta, egy fejezetet pedig maga írt - ráirányítja a figyelmet arra, hogy e tágabb értelmezésben már vizsgálnunk kell a folyamatok mögött meghúzódó okokat a közgazdaságtan és azon belül a pénzügyek területén.

Érdemes áttekintenünk azokat a gazdasági doktrínákat, amelyek azon cselekvéseinket irányítják, amelyek nem a fenntarthatóság irányába terelik - beláthatatlan következményekkel - a jövőt. A könyv szinte egy időben jelent meg Stephen Belgin - Bernard Lietaer: Új pénz egy új világnak [2017] című könyvének magyar kiadásával. Áttekintve Lietaer és szerzőtársa, valamint korábbi szerzőtársai munkáit, továbbá e recenzált mü gazdag irodalomjegyzékét, jól látható, hogy a nemzetközi szakirodalomban ez a kérdéskör jóval nagyobb hangsúlyt kapott régebben is. Magyar nyelven, magyar szerzők tollából azonban ritkán születik olyan mü, amely a fenntarthatóság ezen oldalát vizsgálja, mégpedig e müben szereplő körültekintéssel és alapossággal. Kétségtelen, hogy a tőkés gazdaságra jellemző elvek érvényesülnek világunkban, amelyek a piaci, pénz által közvetített koordinációt hangsúlyozzák [Kornai, 1983]. A pénzhez való viszonyunk lényegesen meghatározza gazdaságunkat és társadalmunkat, ezért elengedhetetlen (volna) e vonatkozások alapos vizsgálata, reformjavaslatok kidolgozása, hazai kutatók részéről csakúgy, mint külföldön. Mindezek alapján elmondható, hogy a könyv e perspektívából megközelítve hiánypótló jellegünek tekinthető ma, a magyar könyvpiacon.

A könyv felépítése az általánostól a specifikus kérdéskörök felé tart. Fejezetei mind önálló cikkekként, mind egy kerek, egész mű, összefüggő, láncszerűen egymásba kapcsolódó részeiként is megállják a helyüket. Az első fejezet az elméleti közgazdaságtan terén jelentős eredményeket felmutató Oroszi Sándor munkája, ez után következik Kerekes Sándor írása, amely összekapcsolja a fenntarthatóság gazdasági, környezeti és társadalmi kérdésköreit. Ezek után következnek a fenntarthatóság specifikusan pénzügyi kérdései. A 3. fejezetben Gál Veronika a bankok gyakorlatában vizsgálja a fenntart- 
hatóság megjelenését. Itt többféle megközelítés is lehetséges. A szerző nagy hangsúlyt helyezett a mikrohitelezés Grameen banki modelljének bemutatására, ami kétségkívül az egyik legfigyelemfelkeltőbb példa e területen. A 4. fejezetben Parádi Dolgos Anett mutatja be az önkormányzatok szerepét a helyi pénz kibocsátásában, egyébként az ő munkája a könyv utolsó, 7 . fejezete is, amely a helyi pénzeket mutatja be a hazai gyakorlatban. Varga József az 5. és 6 . fejezetben e pénzek megjelenését, szerepét, nemzetközi tapasztalatait mutatja be, nagy alapossággal.

A közgazdaságtan elmélettörténeti oldaláról közelítő első fejezetben logikus levezetésben találkozunk azzal a problémával, hogy a tudományos fejlődés alapvető irányvonalába helyezkedve a közgazdaságtan miként vált olyan tudománnyá, amely zárt rendszerként gondolkodott a gazdaságról. Alapvető példája ennek a Walras-modell, amelyre mint alapra, valamennyi mainstream közgazdasági elmélet ráépült. Ha e modell müködőképes lenne a gyakorlatban, a gazdaság nem hathatna a környezetre és fordítva, az nem hathatna vissza rá. E nyilvánvalóan téves vélekedés azonban számos további tévedést szül, egy ezek közül, hogy a pénz semleges. Ha ez egy az egyben igaz lenne, akkor pl. a 2008-as pénzügyi válság a reálgazdaságot teljesen érintetlenül hagyta volna. Ahogy a szerző maga összegzi: „Ma már egyértelműnek tűnik - noha a fóáramú közgazdaságtan nem vesz róla tudomást -, hogy a gazdaságok nyílt rendszerekként müködnek, energiájuk annyival nő, amennyivel környezetüké csökken" [2016: 19]. Ezzel sikerül megragadnia a fóáramú, hagyományos közgazdaságtan és a fenntarthatósági elméletek összeegyeztethetetlenségének fö okát. A szerző felhívja a figyelmet a hálózatelmélet kutatási eredményeinek fontosságára, a gazdaság, társadalom, természeti környezet összefüggéseinek megértése terén játszott lényeges szerepére.

A fenntarthatóság problémájával a világ legmarkánsabban akkor szembesült, amikor a Római Klub világmodell becslései, ill. a Meadows jelentés figyelmeztettek minket, hogy hamarosan eljutunk a „szükösség világába”. E jelentések csakúgy, mint egyes korai közgazdasági gondolkodók (pl. Malthus) inkább a túlzottan pesszimista vélekedések közé lettek sorolva, mintsem hogy cselekvésre, változtatásra sarkalltak volna. (Nemcsak a közvélemény, hanem számos tudós, közgazdász, pl. Keynes maga is jóval optimistább volt.) A 2005-ben megjelent D. Meadows - J. Randers A növekedés határai - Harminc év múltán címü írása nem ad okot bizakodásra: a szennyezésben és az ipari, mezőgazdasági termelésben bekövetkezett változások nagyon jól követik az 1972-es elörejelzéseket. A második fejezetben leírtak - hüen az elsőhöz - a föáramú közgazdasági elméletekkel szemben fogalmaznak meg kritikákat. A megközelítések, fogalmak eltérései nagyon is gyakorlati, kézzelfogható következményekkel járnak. A szerző ismerteti a közgazdasági értelemben gyenge és szigorú fenntarthatóság fogalmát és azok - különösen az utóbbi - széleskörủ szakmai elfogadásának akadályait, amelyek az uralkodó közgazdasági elméletek axiómáival ütköznek. Az ENSZ által kidolgozott fogalom a legismertebb, közérthető és jól illeszthető a hagyományos közgazdasági gondolkodásba. E fogalom a jólét maximalizálásán alapul, azonban alkalmatlan jelentős változás elérésére: ha nem nézünk szembe azzal a kellemetlen ténnyel, hogy a fejlett országokban a fogyasztási szintet is csökkenteni kellene, a megoldások számos szakértő szerint felszínesek. Talán ez a fö oka a szerző bevezető mondatában ismertetett ténynek, hogy a környezetgazdaságtan két egymás mellett létező irányzatot mondhat magáénak: egy olyat, amely elegendőnek tartja a hagyományos közgazdasági elméletek - egyébként jelentős - mértékủ reform- 
ját, és egy másikat, amely pedig teljes paradigmaváltást követel. Egyébként később, a negyedik alfejezetben visszaköszön a probléma: az Easterlin-paradoxon értelmében az emberek megelégedettsége már nem nő együtt a gazdagsággal, tehát a jólét, boldogságérzet fokmérője nem lehet a minél magasabb szintü fogyasztás. Csíkszentmihályi szerint pedig nem a fogyasztástól nő a megelégedettség, boldogságérzet, hanem magának a fogyasztásnak az élményétől, ami viszont fenntarthatatlan pazarlást eredményez. Mindezek az állítások, eredmények cáfolják, hogy a haszonmaximalizáló fogyasztóról alkotott feltevések úgy fogadhatóak el, ahogy a mainstream közgazdaságtan ezt értelmezi.

A téma közgazdasági elméletei közül természetesen nem maradhat ki az externáliák összefoglaló, lényegre törő tárgyalása. A két további alfejezet gyakorlatias, közösségi pénzügyek témakörébe illeszthető témakört jár körül. A fenntarthatóság egyfajta, az előzőeknél jóval szűkebb értelmezése az államháztartás fenntarthatóságának kérdésköre. Bizonyos értelemben azonban a fenntarthatóságnak ez a dimenziója is komoly problémák forrása lehet, jelentősen korlátozhatja jövőbeni lehetőségeinket. A szerző a jelenérték számítás megújuló természeti erőforrásokkal kapcsolatos problematikájával is sokat foglalkozik. A következő, kihagyhatatlan, közgazdaságilag nagy jelentőségü rész a gazdasági növekedés és a fenntartható fejlődés kapcsolata. A már említett, a fogyasztás és gazdasági növekedés kapcsolatát vizsgáló részen túl arra a kérdésre helyeződik a hangsúly, vajon a növekedés pozitív hatásai mindig túlszárnyalják-e a negatívakat? Az ötödik alfejezet „Bolygónk határai és a reziliencia” címmel ismét a természet és az emberi tevékenység kényes egyensúlyának problémáit vizsgálja.

A bankrendszer társadalmi felelösségének tárgyalásakor az „alternatív” vagy „,közösségi”, ill. „civil” bankoké a föszerep; jelenleg már magyar szereplője is van ennek a típusnak, a MagNet Magyar Közösségi Bank. Az ilyen típusú bankok müködési elveik szerint gazdasági, társadalmi, szociális és környezetvédelmi szempontokat egyaránt szem elött tartanak. Ezzel nyilvánvalóvá teszik, hogy a kereskedelmi bankok tevékenysége nem értéksemleges. Ehelyütt érdemes megjegyezni, hogy a közfelfogásban - ahogyan erről már többen tudományosan is értekeztek - a hagyományos banki szerep értéksemleges, mert az emberek racionálisan hoznak gazdasági döntéseket annak érdekében, hogy az maximalizálják személyes hasznukat és jólétüket [de Clerk, 2010]. Lietaer éppen ennek szentel egy fejezetet [Belgin - Lietaer, 2017] és kifejti, hogy önmagában csak a megtérülést és a hasznot szem előtt tartó gazdálkodás sem értéksemleges, mert egyes emberek gazdagodását és mások elszegényedését idézi elő. Hiába tekintjük úgy a világot, mint ahol tökéletesen versenyző, lehetőségeikben korlátlan szereplők vannak jelen, ha a világban alapvetően a monopolizálódás, a jövedelemdifferenciák növekedése a jellemző. A jelen gazdasági viszonyok között a jövedelem termelésére alkalmas tőkét, banki hiteleket csak azok kaphatják, akik már jelentős vagyonnal és jövedelemmel rendelkeznek, így a szegénységből kitörni lehetetlen. Ez esetben nem kívánatos mértékü a jövedelemkoncentráció, a korábbi társadalmi viszonyok fenntarthatatlanok. Az egyébként bírálatoktól sem mentes mikrohitel rendszer Grameen banki modellje egyrészt lelkesítő, másrészt a hasonló hazai és nemzetközi kezdeményezések vegyes sikere miatt elgondolkodtató. A szerző a hazai adaptációhoz értékes észrevételeket füz és javaslatokat tesz. Végül a társadalmi és szociális vállalkozások kerülnek górcső alá és a magyar társadalmi vállalkozások müködését akadályozó tényezők is összegyüjtésre kerülnek. 
A könyv negyedik fejezete az önkormányzatok szerepét mutatja be a helyi pénz kibocsátásában és müködtetésében. A pénzügyi rendszer instabilitása nagyon komoly fejtörést okoz korunk elméleti és alkalmazott pénzügyekkel foglalkozó közgazdászainak. Az első fejezetben figyelmünkbe ajánlott hálózatelméletek megoldása a stabilitás javítására a sokféleség, a diverzitás, az ennek nyomán kialakuló nagyfokú alkalmazkodóképesség. Talán éppen ennek megfelelően napjainkban pénzfajták kialakulásának vagyunk tanúi: pénz- és pénzügyi eszköz fogalmak határmezsgyéjén található pénzügyi innovációk, pénzfunkciók jelentős részét betöltő utalványok, virtuális pénzek és marketing célból létrehozott „pont pénzek”. És még emellett is jelentős szerepet kapnak a helyi pénzek, amelyek létrehozásának okaival, jellemzőivel, helyükkel a pénzpiacon mindenképpen érdemes foglalkozni. A fejezet egyfajta bevezetés a könyv hátralévő részében részletesen kifejtett helyi pénz témakörhöz. A helyi önkormányzatok szerepét ismerteti az államháztartás rendszerében és azok működési sajátosságait annak tükrében, miként képes a helyi közösséget szolgáló és általa épített helyi gazdaság jól funkcionálni, a helyi termékek és szolgáltatások hol helyezkednek el a fogyasztott javak palettáján.

Az ötödik fejezet bemutatja a helyi pénzek történetét és lényegét, jogi hátterét, müködtetését, hatásait, kritikus jellemzőit. Gesell munkássága is bemutatásra kerül. A forgásbiztosított pénz akár egészséges megoldás is lehetne e problémára (a helyi pénz ilyen, „őskamat” nélküli pénz), ugyanakkor a helyi pénz napjainkban csak egy erős, központi valutával a háttérben lehet igazán sikeres. Azt a tanulságot is levonhatjuk a fejezetből, hogy, noha gyakran hallunk a különböző kiegészítő pénznemek elönyös vonásairól a valuta stabilitásának szempontjából, helyi szinten természetesen nem ez jelenik meg a helyi pénz kibocsátásának elsődleges ösztönzőjeként. Feltehetőleg nem is elsősorban a pénz részleges „seigniorage” hatása, a be nem váltott pénz burkolt bevétel jellege ez a tényező, hanem a következők: a marketingelőnyök, a helyi együttmüködés és ezáltal a helyi gazdaság fellendítése, ill. a közösség összetartozás-érzését erősítő jellege.

A könyv utolsó két fejezete példák sokaságát sorakoztatja föl a helyi pénzek világából. Az egyik nemzetközi példákat mutat be, a másik minden olyan magyarországi kezdeményezést, amely említésre méltó. A szerző kutatásai alapján a helyi pénzek földrajzi megjelenése a fejlett gazdaságokban, elsősorban az Egyesült Âllamokban és Nyugat-Európában jellemző. Két helyi pénzt, a svájci WIR-t és a német Chiemgauert részletesen is megismerhetünk. Bár jelentős eltérések vannak a két pénz között, mégis mindkettő jól szemlélteti a korábbi elméleti bemutatás során leírtakat. A hazai helyi pénzekről aktuális, részletes körképet kapunk; a soproni kékfrank, a balatoni korona, a hajdúnánási bocskai korona, az alsómocsoládi rigac és a tokaji dukát mindegyike eltérő nagyságú forint fedezettel rendelkezik, kismértékben eltérő célokkal hozták létre, más szabályokkal - az érvényben levő jogi szabályozás adta lehetőségeken belül. Mindezek ellenére mindegyik szép példája a helyi kezdeményezéssel létrejött pénzeknek. Gyorsítják a pénz forgási sebességét, élénkítve a helyi gazdaságot, erősítik a közösségi szellemet.

A fenntarthatósággal kapcsolatos dilemmák és pénzügyek közötti összefüggések cseppet sem eröltetettek. A mai gazdaság viszonyrendszerében a pénz áll központi helyen. Érdemes mindkét fontos kérdéskört egyszerre, együtt körüljárni. A gazdaság harmonikus müködése, a jövő generációira átörökített világunk érdekében folyamatosan vizsgálni kell az előttünk álló lehetőségeket, mindkettő fontos szerepet kell, hogy betöltsön a jövőről való gondolkodás során, mégpedig összefüggéseiben vizsgálva. 
Jó szívvel ajánlom e könyvet mindenkinek, akit a fenntarthatóság pénzügyi aspektusai érdekelnek, de azoknak is, akik e helyi pénzekről vagy a pénz közösségépítő szerepéről, a társadalmi felelősségvállalásban betöltött szerepéről szeretnének részletesebben tájékozódni. Egyetemi hallgatók és oktatók, kutatók, de egyszerüen csak a téma iránt érdeklődők is találnak benne közérthető és érdekes információkat.

\section{FELhASZNÁLT IRODALOM}

Belgin, S. - Lietaer, B. (2017): Új pénz egy új világnak. Bankráció Kft, Budapest. de Clerk, F. (2010): Ethical Banking http://www.social-banking.org/fileadmin/isb/Artikel_und_Studien/de_Clerck_Ethical_Banking.pdf Letöltve: 2017. 07. 12.

Kornai J. (1983): Bürokratikus és piaci koordináció. Akadémiai székfoglaló, Budapest. Meadows, D. - Randers, J. (2005): A növekedés határai - Harminc év múltán. Kossuth Kiadó, Budapest.

Juhász Zita ${ }^{2}$ 